\title{
Determinants of Retail Banking Efficiency: A Case of Vietcombank Branches in the Mekong-Delta Region
}

\author{
Thi Thu Diem LE ${ }^{1}$
}

Received: April 17, 2020 Revised: May 03, 2020 Accepted: June 07, 2020

\begin{abstract}
This study focused on researching the factors affecting retail banking efficiency of Vietcombank branches in the Mekong-Delta region. By collecting data from financial statements from 15 branches of VCB in the Mekong-Delta Region between 2015 and 2018 , the paper applies DEA estimation to measure the effectiveness of retail banking activities and uses the Tobit regression model to identify factors affecting retail banking efficiency. The results demonstrate that the retail banking efficiency of branches averaged $52.5 \%$ during the period. The rating result shows the branches in An Giang, Can Tho, Dong Thap, Kien Giang, Long An, Phu Quoc and Tra Noc rank at the top technical efficiency. In group of medium efficiency, there are branches in Soc Trang, Tien Giang and Vinh Long. In the category of the poor efficiency are the branches in Bac Lieu, Ben Tre, Ca Mau, Chau Doc and Tra Vinh. The results also show that bank scale-related factors, capital adequacy, credit quality, time specific and region impact significantly the retail banking efficiency. The research not, only contributes to enriching the empirical research method but also is significant for the management activities in business developing strategies, improving the operational efficiency of Vietcombank in the region.
\end{abstract}

Keywords: Financial Institution, Retail Banking Efficiency, Bank Branches, Mekong-Delta Region

JEL Classification Code: G21, L25, M11

\section{Introduction}

The development of retail banking services is becoming the operation orientation of most commercial banks in Vietnam, creating an extremely competitive atmosphere to reach retail customers. Practically, comparing to focusing entirely on large corporate clients, retail banking provides steady income with relatively little risk. To become the leading retail bank in Vietnam (VCB) (Vietcombank, 2018), the retail segment of VCB has been identified as a key activity in recent years. The Mekong-Delta Region

${ }^{1}$ First Author and Corresponding Author. Deputy Dean, School of Economics and Law, Tra Vinh University, Vietnam [Postal Address: No. 126, Nguyen Thien Thanh, Hamlet 4, Ward 5, Tra Vinh City, Tra Vinh Province, 940000, Vietnam] Email: Ittdiem@tvu.edu.vn

(c) Copyright: The Author(s)

This is an Open Access article distributed under the terms of the Creative Commons Attribution Non-Commercial License (http://Creativecommons.org/licenses/by-nc/4.0/) which permits unrestricted noncommercial use, distribution, and reproduction in any medium, provided the original work is properly cited.
(MDR) of VCB with 15 branches accounts for nearly $15 \%$ of revenues of the whole system (Vietcombank, 2018) contributing significantly to the development in the retail segment of VCB. With a large proportion of the population accounting for $20 \%$ of the country's total population, the Southwest region is an area considered to be the largest retail market in the country (GSO, 2018). However, the MDR has only contributed $4 \%$ of the retail revenue in the whole system (Vietcombank, 2018). Obviously, the market potential in this area has not been fully exploited yet. Meanwhile, other commercial banks in Vietnam are also expanding and establishing many branches in this area. The potential of the retail market in this area has not been fully exploited. Therefore, it is necessary to evaluate the effectiveness of the retail banking operations of the branch network.

The focus of most of the academic studies on the performance of a commercial bank is found at the institutional level (Adusei, 2016; Andries, 2011; Barros, Ferreira, \& Williams, 2007; Batir, Volkman, \& Gungor, 2017; Girardone, Molyneux, \& Gardener, 2004), while 
research at the branch level is rare. Indeed, Paradi and Zhu (2013) found 195 studies at the institutional level and only 80 at the branch level. Meanwhile, research at the branch level focused on evaluating factors affecting the effectiveness of management activities in different branches. Clearly, the efficiency of an entire banking organization is created at the branch level, and even in times when technological advances are creating a drastic change in the habits of consumers, bank branches still play an important role in the banking system (Quaranta, Raffoni, \& Visani, 2018). The main contributor to the efficiency of an entire banking organization is created from bank branch operating efficiency.

From the management perspective, an analysis at the branch level can provide helpful decision support (LaPlante \& Paradi, 2015). Meanwhile, in Vietnam, there has not been much research conducted to assess the issues related to the performance of branches, especially the individual business segment of the branches. There are only a few studies in the field of retail banking, while most focused on exploiting the performance measurement of a specific branch, but did not extensively study a list of many exception branches. However, all these studies have assessed the performance at branch level for all branch activities rather than focusing on the retail segment. Meanwhile, almost all studies of banking performance in Vietnam have concentrated on the institutional level over different periods (Ngan, Thao, \& Huan, 2015; Ngo, 2010, 2015; Nguyen \& Simioni, 2015; Stewart, Matousek, \& Nguyen, 2016).

For all these reasons, on the practical and theoretical levels, it is necessary to conduct in-depth studies on the retail performance of the commercial bank of VCB branches in MDR. Therefore, this paper will focus on addressing the following issues, including assessing the status of retail service operations based on descriptive statistic methods and Quantitative Data Envelopment analysis, identifying factors affecting VCB's retail banking performance in the MDR by the Tobit regression model, and proposing solutions to improve the efficiency of MDR.

\section{Literature Review}

\subsection{Retail Banking Efficiency}

The retail banking activities have focused on embedding core values into retail and wholesale models for almost all the Vietnam commercial banks. There are many approaches in measuring the effectiveness of bank branches; there are some common approaches: (1) proportional parameters traditional applications (Coelli, Rao, O'Donnell, \& Battese, 2005; Quaranta et al., 2018); (2) a multi-factor approach through regression functions (Berger, 1993; Boufounou, 1995; Hensel, 2003; Murphy \& Orgler, 1982); and (3) a multi-factor approach based on the determination of marginal functions of production or cost (Avkiran, 1999; Quaranta et al., 2018; Sharma, Sharma, \& Barua, 2013).

The first and most traditional approach is Proportion (Quaranta et al., 2018). Three types of common ratios proposed to measure the performance of a bank branch, include Partial factor productivity index (PFPI), Performance index (EI), and Total factor productivity index (TFPI). PFPI is the ratio of value created by the bank (total loans, intermediary deposits, added value, etc.) or a measure of the total workload (number of transactions) to the number of employees (measured by the number of employees, number of hours worked, computers, etc.). In contrast, EI is the ratio of input costs to revenues, total assets, other costs to quantify the value from bank operations. Finally, the TFPI considers labor and capital inputs in Cobb-Douglas production function (Coelli et al., 2005). The Proportion approach is an important measure of efficiency because it provides information about the performance of each branch, and it is easy to calculate and understand. However, the use of these ratios has several limitations which are (1) because these ratios remain unchanged in proportion, this is not always effective in bank branch efficiency, and (2) these ratios do not support innovation initiatives (Paradi \& Zhu, 2013). Specifically, the calculation of PFPI ratios only considers one input at a time, which provides an inadequate view of bank branch efficiency. This is unsuitable for the multi-dimensional nature of branch efficiency (Quaranta et al., 2018).

The second approach to measure the efficiency is regression-based approaches in which the output measure is considered a dependent variable and a series of input measure are considered independent variables (Berger, 1993; Boufounou, 1995; Hensel, 2003; Murphy \& Orgler, 1982). Nevertheless, the method still has some limitations. Firstly, it requires selecting a production function or identifying predefined cost. Secondly, standard regression can only manage multi-input relationships - one output while at the bank branch, the various inputs (labor, machinery, space, financial funds, etc.) are used to generate multiple outputs (deals, mortgages, loans, customer satisfaction, etc.). Finally, a standard regression model can only show the average level of efficiency without providing a measure of inefficiency comparing to the best (Soteriou, Karahanna, Papanastasiou, \& Diakourakis, 1998). Although this is a useful forecasting tool to achieve the average expected efficiency value for a new branch, it does not assess the inefficiency of existing branches.

The third approach to measure efficiency is based on the production function to determine production or cost margin. The best-known approach is using the frontier function approach (Quaranta et al., 2018; Sharma et al., 2013), which includes parametric approaches (including DFA, SFA and TFA models) and non-parametric approaches 
(including DEA and FDH models). Many reviews of efficiency measurement at the bank branch level show that two research directions are commonly used: (1) the studies measuring the efficiency of bank branches, and (2) the studies comparing the effectiveness of branches among themselves or among different measurement approaches. Firstly, in terms of measuring the efficiency of bank branches, studies often select a DEA model to measure the effectiveness of branches. Indeed, Cook, Hababou, and Tuenter (2000) developed a specific DEA approach to managing situations in which inputs relate to a variety of activities. Camanho and Dyson (2005a) defined the DEA model to measure cost-effectiveness when price information is not complete. Second, the comparison approaches find out the reason for the difference in efficiency measurement.

In this study, the author intends to choose two approaches including parameter-based approach and single-rate approach through multi-factor analysis with production function/ marginal cost analysis using DEA model for describing a complete picture of retail effectiveness of VCB branches in the MDR. The reasons for this choice are: (1) the simplicity and ease to collect data when using the available parameters in accounting reports to calculate the efficiency measurement ratio of the branch; (2) the access to production and cost boundary functions for a branch will help to understand the effectiveness of each branch's operations clearly when using a data set with a large combination of factors at the same time; (3) DEA is a fairly common, easy-to-understand techniques that have been applied by many researchers, not only in Vietnam, but also in the field of banking efficiency assessment; and (4) in applied research, the author does not focus on developing a new approach, or any extended evaluation technique. Instead, he wants to use the most useful, easy-to-understand and most popular tools to obtain a comprehensive picture when implementing the objective of assessing the status of retail effectiveness of bank branches.

\subsection{The Factors Affecting the Retail Banking Efficiency}

In this paper, retail banking service is a banking service that provides financial services and products to individuals, small- and medium-sized businesses (SMEs) over the Internet. In other words, customers can have direct access to banking services and products through electronics, telecommunications and information technology. Regarding the performance of retail services, there are many international studies mentioning factors affecting the performance of banks (Andries, 2011; Sherman \& Gold, 1985; Vallascas $\&$ Keasey, 2012). The factors affecting the performance of the retail banking operations at the branch level include two groups, i.e., subjective factors and objective factors. While subjective factors relate to the specific characteristics of the bank such as branch size, capital adequacy, loan quality, expenditure-related factors, age of branch (Sherman \& Gold, 1985), objective factors include factors related to time and geographical specific factors (Sherman \& Gold, 1985) and others related to cultural differences, such as the scale of the economy, economic growth, population, retail market of goods and services.

Bank size factor: the logarithm function for total assets is used as a measurement for bank size (Majeed, Jun, Zia-UrRehman, Mohsin, \& Rafiq, 2020; Ngo, 2015; Stewart et al., 2016). Larger banks tend to be more cost-effective than their smaller counterparts (Hauner, 2005; Othman, Abdul-Majid, \& Rahman, 2017), which means that larger banks save more on operating costs. Indeed, economies of scale show that banks operate effectively and do not waste resources. In other words, economies of scale can result in lower marginal costs. Indeed, Othman et al. (2017) found that bank size has a positive relationship with the efficiency of banks. Besides, in this paper, the number of transaction points was used to express bank size. It is argued that the more transaction points the bank has, the more revenue it will generate. If the branches work effectives they will use its finance to expand their size through opening more new transaction points.

H1: Larger branches (larger total assets and more branches) are more effective in retail operations.

Showing a similar tendency, banks with higher capitalization tend to be more efficient (Kwan \& Eisenbeis, 1997; Sarmiento \& Galán, 2017). The ratio of equity to total assets is usually represented by capital adequacy levels. This index indicates the strength of capital and bank health. It is found that banks with higher market capitalization tend to be more efficient. Similarly, Mester (1996) and Girardone et al. (2004) showed that the correlation between capital adequacy ratio and the ineffective ratio is negative, which means that the relationship between capital adequacy ratio and efficiency is positive.

H2: Branches with higher capital adequacy ratios are more effective in retail banking operations.

Credit quality: The bad debt ratio can be used to measure loan quality (Molyneux \& Thornton, 1992). This means the bigger ratio signifies bad loan quality. Manlagñit (2011) shows the negative relationship between the bad debt ratio and efficiency. It is because larger bad debts increase financial risks, leading to a decrease in profit. A common finding is that more efficient banks have lower levels of bad debt (Berger \& Mester, 1997). Similarly, Kwan and Eisenbeis (1997) reported that an inefficient bank is associated with higher loan losses. The retail operations also share the same approach as all other banking activities. In particularly, 
credit is an important part of the retail operation structure, so credit quality is an important factor of efficiency of retail operations. Besides, Stewart et al. (2016) also took this factor into consideration of factors affecting the banking performance.

H3: Branches with higher credit quality are more effective.

Bank expenses: The ratio of total operating expenses to the total operating income can be used to analyze the relationship between bank costs and efficiency (Dao \& Nguyen, 2020). Banks with higher costs may overuse inputs, then they are less efficient. Berger and Mester (1997) and Bauer, Berger, Ferrier, and Humphrey (1998) found a negative correlation between bank efficiency and cost-toassets ratio. Indeed, if a bank uses an excessive amount of input for the business, the income may fail to cover the banking expenses. Generally, it is difficult to divide clearly which is the input cost for a retail operation. However, general operating expenses also contribute to the efficiency of retail operations. The higher the ratio of expenses to total assets is, the lower the efficiency of retail operations will be. Besides, specific expenditures such as employees, depreciation and other activities also have a significant impact on retail performance. Because retail activities are mainly provided by employees, promoted by using assets and facilities, if these expenses are too large, it will lead to inefficient retail business.

H4: The ratio of expenses to operating income is negatively correlated with performance in retail banking.

Berger and Mester (1997) and Bauer et al. (1998) found a negative correlation between bank efficiency and cost-toassets ratio. These expenses include expenses on operations, staff expenses, and depreciation expenses. Regarding the uptime, it is argued that the larger bank may have a chance to gain more experience, knowledge and understanding of cultural diversity so that the bank can have better operational management, resulting in better and more effective operations (Mester, 1996). In short, the larger banks may be more effective in retail banking.

H5: The ratio of employee expenses to total expenses is negatively correlated with performance in retail banking.

Geographically, Das, Ray, and Nag (2009) and Paradia, Rouatt, and Zhu (2011) suggested that banks in different regions or localities perform differently. This means that geographical differences significant affect the performance of retail banking.
H6: The ratio of depreciation expense in the total expenses is negatively correlated with performance in retail banking.

Age: Age is measured in years of operation. The argument is that the older the bank, the more experience, knowledge and better grasp of the local culture for a better management (Mester, 1996). Schaffnit, Rosen, and Paradi (1997) found evidence that rural banks had higher average efficiency than urban branches. Besides, many previous studies (Deville, 2009; Noulas, Glaveli, \& Kiriakopoulos, 2008; Schaffnit et al., 1997) suggested that banks operating in areas with greater economic growth, larger population size, and higher average income are more likely to function more effectively.

H7: The older the bank, the more effective the retail banking.

Structural changes in banking performance over time show the effects of changes in the regulatory environment. Indeed, Kwan and Eisenbeis (1997) found that average inefficiency seems to diminish over time. Bhattacharyya, Lovell, and Sahay (1997) reported a decreasing trend in efficiency for commercial banks in India between 19861991. Meanwhile, Casu and Molyneux (2003) found a slight improvement in efficiency over time for European banks except for banks in Italy.

H8: There is a positive relationship between time factors and banking efficiency. This implies that retail banking business activities become more efficient when they adapt gradually to the competitive environment.

Geographical features: Factors related to differences in geographical characteristics significantly affect the business operations. The differences include the population characteristics, the retail market of goods and services, consumption, the size of the local economy and political characteristics. The arguments in previous studies (Deville, 2009; Noulas et al., 2008; Schaffnit et al., 1997) suggested that bank operations are likely to be more efficient the greater economic growth areas they are located, the larger the population size and the higher income.

H9: Differences in geographical characteristics affect significantly the performance in retail banking.

The banking efficiency trend over time also correlates with the performance. Indeed, Kwan and Eisenbeis (1997) found that average inefficiency appeared to be diminishing over time. Bhattacharyya et al. (1997) found that the efficiency trend was decreasing over time during 1986-1991. 
H10: Banks in higher economic growth localities have higher efficiency in retail banking.

H11: Banks in localities with higher per capita income have higher efficiency in retail banking.

H12: Banks in the more popular localities have higher efficiency in retail banking.

Figure 1 summarizes the conceptual framework of this research.

\section{Research Methodology}

\subsection{Analytical Framework}

The analytical framework of this paper is modeled in Figure 2.

\subsection{Efficiency Measurement}

This paper uses Data Envelopment Analysis (DEA) to measure the retail banking efficiency of 15 branches in the period 2015-2018. This is a marginal approach to construct an effective non-parametric convex surface so that the observed points will not be higher than the production possibility frontier. This method is also used in many studies such as Banna, Ahmad, and Koh (2017), Stewart et al. (2016), Nguyen and Simioni (2015), Ngo (2010), Camanho and Dyson (2005b), Das et al. (2009), Deville (2009) and Quaranta et al. (2018) to measure banking efficiency. The DEA model used in this paper focuses primarily on the technical efficiency-TE under the assumption of a nonincreasing return to scale (Variable Return to Scale (VRS) DEA) by Banker, Charnes, and Cooper (1984). Accordingly, output variables including outstanding loans, capital mobilization, and interest income are found in studies by Stewart et al. (2016), Nguyen and Simioni (2015), Ngo (2010), and Ngo (2015). The cost input variable is found in most studies, but it is specific in different cost categories. While Nguyen and Simioni (2015), Ngo (2010) and Das et al. (2009) consider labor costs an important input, Deville (2009) and Camanho and Dyson (2005b), eliminate labor costs from operating costs. The expected input-output variables in the DEA model are shown in the table below (see Table 1):

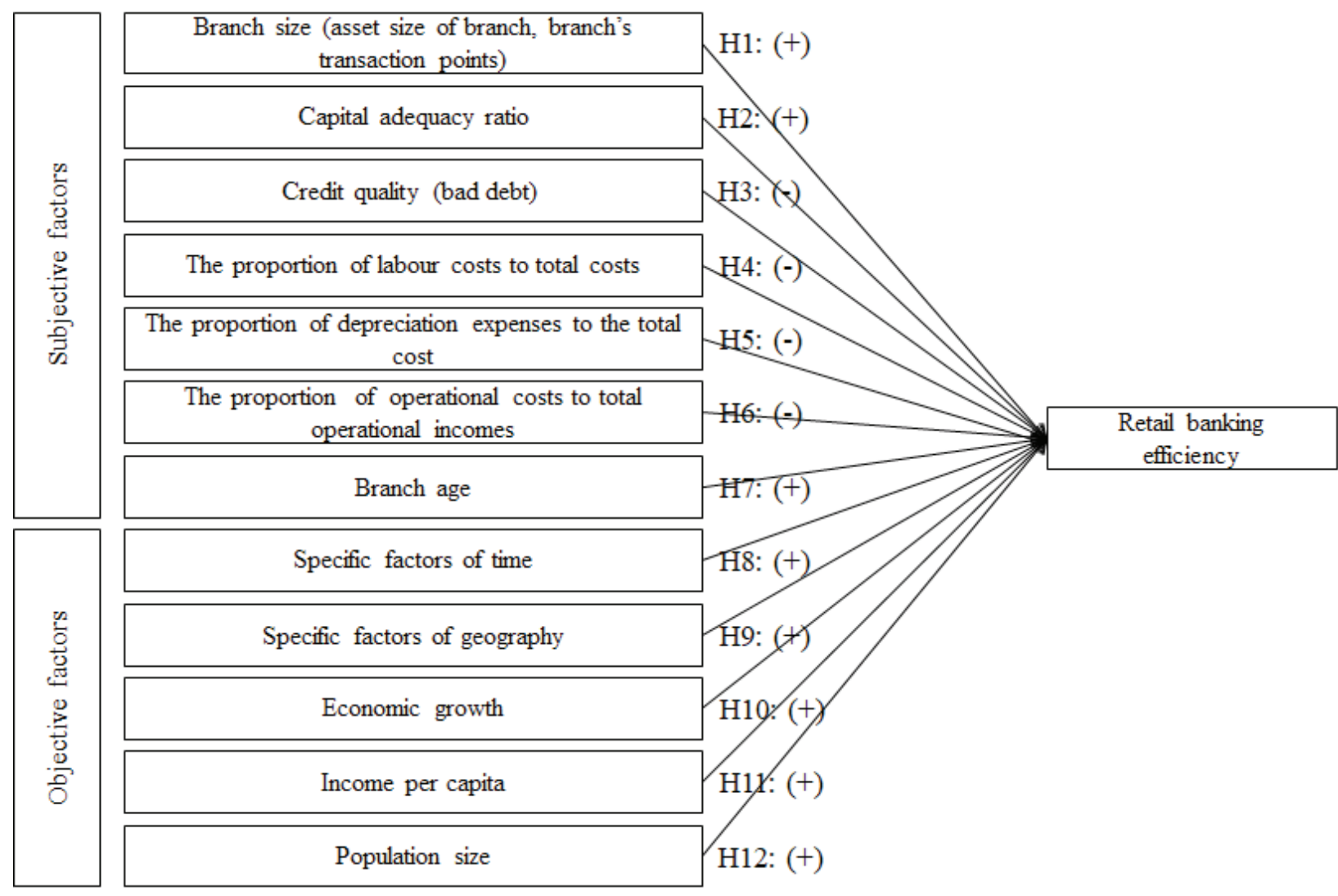

Figure 1: Theoretical model 


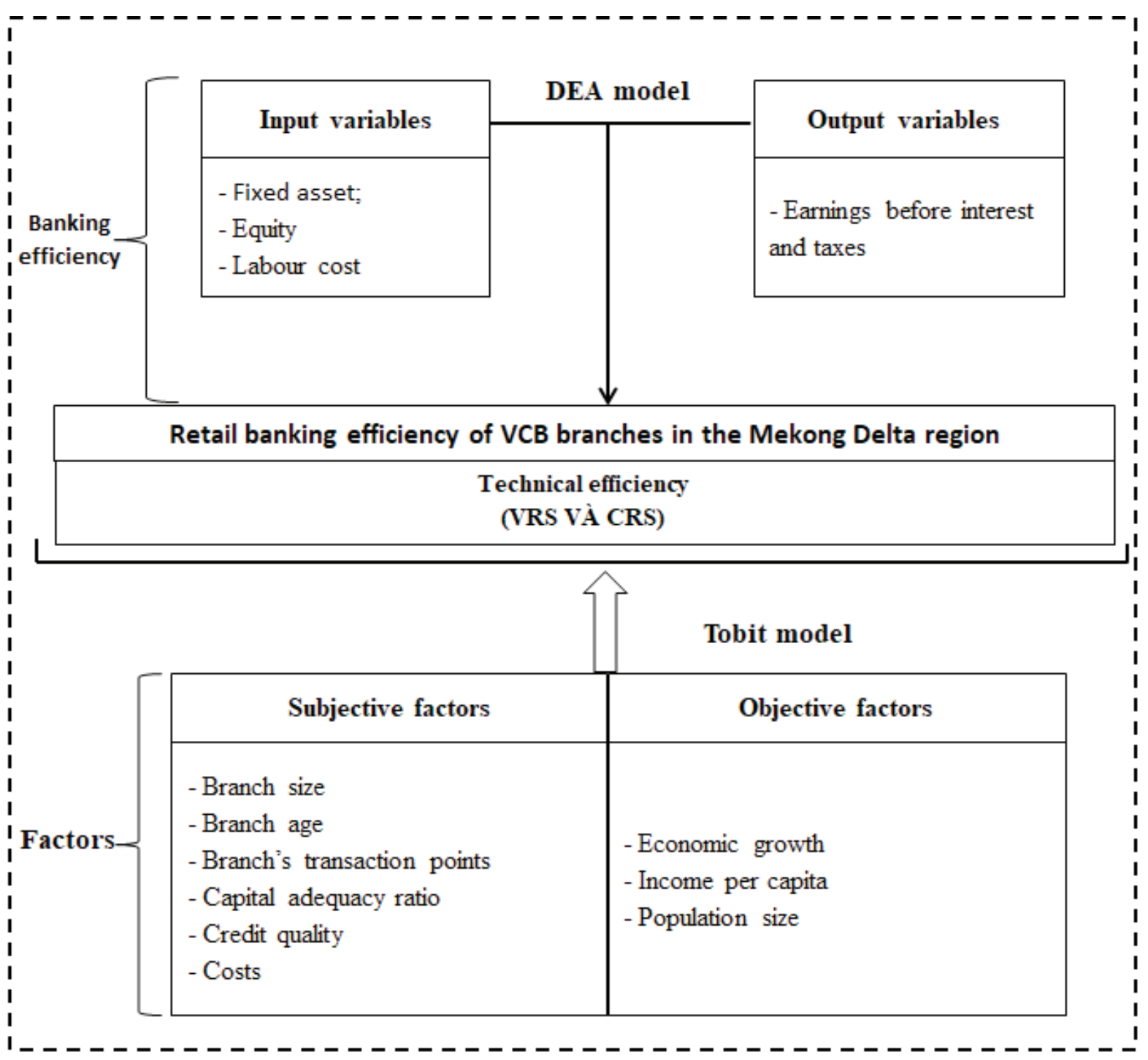

Figure 2: Analytical framework

Table 1: List of input and output variables used in the DEA model

\begin{tabular}{|l|l|}
\hline \multicolumn{1}{|c|}{ Output variables } & \multicolumn{1}{c|}{ Input variables } \\
\hline Total retail loans; & Number of employees; \\
Total retail mobilized funds; & Labor costs; \\
Total net interest income for retail banking; & Non-interest expense; \\
Non-interest income; & Total operating expenses in providing service; \\
\hline
\end{tabular}

Besides, this paper used technical efficiency scores as branch ranking criteria. A grade-A group includes branches with high technical efficiency score from 0.8 to 10 . Grade $B$ includes branches with good quality and relatively efficient operation, with the score of between 0 . and 0.8 . Lastly, branches of grade $\mathrm{C}$ have a technical efficiency score from 0 to 0.5 , including branches of average and poor technical efficiency. Ranking criteria is only a relative point scale proposed by this study to rank the branches. The classification of each branch group is important for managers to determine whether the branch operates effectively or not. 


\subsection{Factors Affecting Retail Banking Efficiency}

Finally, to identify and analyze the factors affecting the retail banking performance of $\mathrm{VCB}$ branches in MDR, a regression model was run. With the censored sample, the research applies the Tobit model to analyses the factors affecting the retail banking performance of VCB branches in MDR from 2015 to 2018. Specifically, vrste_banle is a dependent variable representing the retail banking performance score of the branch (see Table 2).

\subsection{Data}

The main data used in this study including secondary data are collected from business results and annual balance sheets of 15 MDR branches in the research period as well as data from the official website of VCB.

\section{Results}

\subsection{Assessing the Retail Banking Efficiency of VCB Branches in MDR}

Retail banking efficiency has improved gradually throughout the 2015-2018 period. A consistent average increase in efficiency from 0.420 to 0.685 (see Table 3). Although there have been positive changes, the technical efficiency of branches maintains average over the period. It can be seen not yet taking full advantage of the inputs in the retail activities of the branches. This figure also shows

Table 2: List of independent variables in Tobit model

\begin{tabular}{|c|c|c|c|c|}
\hline Variables & Description & Measurement & Unit & Studies \\
\hline Quymo & $\begin{array}{l}\text { Branch size - asset } \\
\text { size of branch }\end{array}$ & Logarithm of total assets & & $\begin{array}{l}\text { (Ngo, 2015); } \\
\text { (Stewart et al., 2016); } \\
\text { (Abdul-Majid, Saal, \& Battisti, 2010) }\end{array}$ \\
\hline Sodiemgd & $\begin{array}{l}\text { Branch size - branch's } \\
\text { transaction points }\end{array}$ & $\begin{array}{l}\text { Branch's transaction points } \\
\text { including headquarters of } \\
\text { the branch }\end{array}$ & $\begin{array}{l}\text { transaction } \\
\text { points }\end{array}$ & $\begin{array}{l}\text { (Stewart et al., 2016); } \\
\text { (Deville, 2009); } \\
\text { (Schaffnit et al., 1997) }\end{array}$ \\
\hline Antoanvon & Capital adequacy ratio & $\begin{array}{l}\text { The ratio of capital to total } \\
\text { assets }\end{array}$ & $\%$ & $\begin{array}{l}\text { (Mester, 1996); } \\
\text { (Girardone et al., 2004) }\end{array}$ \\
\hline Tylenoxau & $\begin{array}{l}\text { Credit quality (bad } \\
\text { debt) }\end{array}$ & $\begin{array}{l}\text { The ratio of bad debt to total } \\
\text { loans }\end{array}$ & $\%$ & $\begin{array}{l}\text { (Berger \& Mester, 1997); } \\
\text { (Stewart et al., 2016) }\end{array}$ \\
\hline Rchinhanvien & $\begin{array}{l}\text { The proportion of labor } \\
\text { costs to total costs }\end{array}$ & $\begin{array}{l}\text { The ratio of labor costs to } \\
\text { total costs }\end{array}$ & $\%$ & $\begin{array}{l}\text { (Berger \& Mester, 1997); } \\
\text { (Bauer et al., 1998) }\end{array}$ \\
\hline Rchikhauhao & $\begin{array}{l}\text { The proportion of } \\
\text { depreciation expenses } \\
\text { to the total cost }\end{array}$ & $\begin{array}{l}\text { The ratio of depreciation } \\
\text { expenses to the total cost }\end{array}$ & $\%$ & $\begin{array}{l}\text { (Berger \& Mester, 1997); } \\
\text { (Bauer et al., 1998) }\end{array}$ \\
\hline rchi_thu_hd & $\begin{array}{l}\text { The proportion of } \\
\text { operational costs to total } \\
\text { operational incomes }\end{array}$ & $\begin{array}{l}\text { The ratio of operational } \\
\text { costs to total operational } \\
\text { incomes }\end{array}$ & $\%$ & $\begin{array}{l}\text { (Berger \& Mester, 1997); } \\
\text { (Bauer et al., 1998) }\end{array}$ \\
\hline tuoicn & Branch age & 2018- year of operation +1 & Year & (Mester, 1996) \\
\hline tangtruong & Economic growth & $\begin{array}{l}\text { Gross Regional Domestic } \\
\text { Product }\end{array}$ & $\%$ & $\begin{array}{l}\text { (Noulas et al., 2008); } \\
\text { (Deville, 2009); } \\
\text { (Schaffnit et al., 1997) }\end{array}$ \\
\hline thunhap & income per capita & Income per capita by locality & $\begin{array}{l}\text { Million VND } \\
\text { per person } \\
\text { per month }\end{array}$ & $\begin{array}{l}\text { (Noulas et al., 2008); } \\
\text { (Deville, 2009); } \\
\text { (Schaffnit et al., 1997) }\end{array}$ \\
\hline rdanso & population size & $\begin{array}{l}\text { Percentage of local } \\
\text { population to total population } \\
\text { of MDR (including the } \\
\text { population of } 13 \text { provinces in } \\
\text { the Mekong-Delta ) }\end{array}$ & $\%$ & $\begin{array}{l}\text { (Noulas et al., 2008); } \\
\text { (Deville, 2009); } \\
\text { (Schaffnit et al., 1997) }\end{array}$ \\
\hline
\end{tabular}

vrste_banle $=\beta 0+\beta 1$ quymo $+\beta 2$ sodiemgd $+\beta 3$ antoanvon $+\beta 4$ tylenoxau $+\beta 5$ rchinhanvien $+\beta 6$ rchikhauhao $+\beta 7$ rchi_thu_hd $+\beta 8$ tuoicn + $\beta$ tangtruong $+\beta 10$ thunhap $+\beta 11$ rdanso $+\beta 12$ year $+\beta 13$ idprovince $+\varepsilon$ 
Table 3: Branches technical efficiency over the period 2015-2018

\begin{tabular}{|l|l|l|l|l|l|}
\hline & $\mathbf{2 0 1 5}$ & $\mathbf{2 0 1 6}$ & $\mathbf{2 0 1 7}$ & $\mathbf{2 0 1 8}$ & $\mathbf{2 0 1 5 - 2 0 1 8}$ \\
\hline An Giang & 0.496 & 0.610 & 1.000 & 1.000 & 0.777 \\
\hline Bac Lieu & 0.093 & 0.153 & 0.366 & 0.353 & 0.241 \\
\hline Ben Tre & 0.002 & 0.085 & 0.092 & 0.186 & 0.091 \\
\hline Ca Mau & 0.269 & 0.322 & 0.356 & 0.497 & 0.361 \\
\hline Can Tho & 1.000 & 0.794 & 0.860 & 1.000 & 0.914 \\
\hline Chau Doc & 0.227 & 0.250 & 0.320 & 0.367 & 0.291 \\
\hline Dong Thap & 0.476 & 0.931 & 0.605 & 1.000 & 0.753 \\
\hline Kien Giang & 1.000 & 1.000 & 0.832 & 0.906 & 0.935 \\
\hline Long An & 1.000 & 0.827 & 0.835 & 1.000 & 0.916 \\
\hline Phu Quoc & 0.021 & 0.022 & 0.335 & 1.000 & 0.345 \\
\hline Soc Trang & 0.254 & 0.302 & 0.359 & 0.523 & 0.360 \\
\hline Tien Giang & 0.301 & 0.318 & 0.626 & 0.631 & 0.469 \\
\hline Tra Noc & 1.000 & 1.000 & 1.000 & 1.000 & 1.000 \\
\hline Tra Vinh & 0.067 & 0.112 & 0.180 & 0.257 & 0.154 \\
\hline Vinh Long & 0.095 & 0.150 & 0.281 & 0.558 & 0.271 \\
\hline MDR & 0.420 & 0.458 & 0.536 & 0.685 & 0.525 \\
\hline
\end{tabular}

that the efficiency of pure retail operations has many opportunities to improve if they know how to overcome their existing limitations. With the same level of input, if branches know how to push their capacity to improve pure efficiency, it will contribute to increasing profits generated from retail operations and it also expand the overall profit of the branch.

However, the efficiency in some branches has decreased in recent years. These figures also reflect the current situation of retail operations of VCB branches in the MDR during this period. In the context of the global economic crisis, VCB's commercial banking system is also affected. Moreover, Vietnam's banking industry is still young compared to the global banking industry. The diversity of banking services is still narrow, mainly offering traditional products. Modern banking services have been developed, but not yet synchronized. Many development services are not commensurate with their potential. Banking operation management and technology are still weak. The banking risk management of branches is not effective, resulting in a high level of non-performing loans. Technology may reduce operating costs; however, modern technology requires large investments. Due to the limited capital and capacity, the number of small branches could not be fully invested, resulting in lower technical efficiency.

The facts have confirmed that some branches of Group A with high technical efficiency are those with larger assets and capital size such as Can Tho, Tra Noc, Kien Giang, Long An branch. These branches are ranked at the top of technical efficiency ratings (see Table 4). There are some branches with the small scale of assets and capital such as Ben Tre, Ca Mau, Bac Lieu, showing low technical efficiency.

\subsection{Factors Affecting Retail Banking Efficiency of VCB Branches in MDR}

Tobit regression results show the factors of scale, capital adequacy, credit quality, labor spending, experience, and environmental adaptation have a significant effect on the retail banking performance of its branches (see Table 5). Also, the results have not shown any statistically significant evidence that some factors of the business environment such as local economic growth and per capita income have influences on the retail banking efficiency.

Branch size: Contrary to the theoretical expectations, the results show that branch size is negatively correlated with retail banking efficiency $(\mathrm{P}<0.05)$. This result is similar to previous studies Stewart et al. (2016), Deville (2009) and Schaffnit et al. (1997). This implies that the larger the branch size, the lower the retail banking efficiency. It also implies that the branch using the assets in a wasteful manner or having many inefficient transaction points in allocating resources may result in insufficient revenue to cover the operating costs.

Capital adequacy factor: The results show that an increase in capital adequacy level improves retail banking efficiency. This result is statistically significant $(\mathrm{P}<0.01) 1 \%$ with a regression coefficient of 1.59 . The results are similar to the studies of Kaparakis, Miller, and Noulas (1994), 
Table 4: The ratings of VCB bank branches by technical efficiency

\begin{tabular}{|l|c|c|c|c|c|}
\hline \multicolumn{1}{|c|}{ Year } & $\mathbf{2 0 1 5}$ & $\mathbf{2 0 1 6}$ & $\mathbf{2 0 1 7}$ & $\mathbf{2 0 1 8}$ & $\mathbf{2 0 1 5 - 2 0 1 8}$ \\
\hline An Giang & C+ & B & A & A+ & B \\
\hline Bac Lieu & C & C & C & C & C \\
\hline Ben Tre & C & C & C & C & C \\
\hline Ca Mau & C & C & C & C+ & C \\
\hline Can Tho & A & B+ & A & A+ & A \\
\hline Chau Doc & C & C & C & C & C \\
\hline Dong Thap & C+ & A & B & A+ & B \\
\hline Kien Giang & A+ & A+ & A & A & A \\
\hline Long An & A+ & A & A & A+ & A \\
\hline Phu Quoc & C & C & C & A+ & C \\
\hline Soc Trang & C & C & C & B & C \\
\hline Tien Giang & C & C & B & B & C+ \\
\hline Tra Noc & A+ & A+ & A+ & A+ & A \\
\hline Tra Vinh & C & C & C & C & C \\
\hline Vinh Long & C & C & C & B & C \\
\hline
\end{tabular}

Mester (1996) and Girardone et al. (2004). It implies that when the capital adequacy ratio increases by $1 \%$, the retail banking efficiency will increase by 1.59 points.

Credit quality: The results show that the bad debt ratio is negatively correlated with retail banking efficiency $(\mathrm{P}<0.01)$. This result is similar to some previous studies (Berger \& Mester, 1997; Kwan \& Eisenbeis, 1997; Molyneux \& Thornton, 1992; Stewart et al., 2016). This implies that the higher the ratio of non-performing loans, the lower the retail banking efficiency.

Operating expenses: The results show that the higher the spending levels, the lower the efficiency of the operation, where the staff spending factor and the ratio of operating expenses to total operating income are significant at $\mathrm{P}<0.05$ and $\mathrm{P}<0.01$, respectively, in retail banking efficiency. This implies that when branches increase their labor expenditure by $1 \%$ and increase their operating expenses as a percentage of total operating revenue by $1 \%$, retail banking efficiency decreases by 1.15 points and 0.6 points, respectively. This result provides suggestions for policies to branch management. This result is similar to the studies of Berger and Mester (1997) and Bauer et al. (1998).

Branch age: The results show that branch age is positively correlated with the retail banking efficiency at $\mathrm{P}<0.01$. This implies that the more experienced in operation the branch is, the more efficient they are. The results are similar to previous studies of (Mester, 1996).

Factors related to the business environment: The factors such as economic growth, income, and population are expected to contribute to the retail banking efficiency. The regression results show that there is no evidence that economic growth and average income affect retail banking efficiency as initially expected. This may be because the growth and income data collected during the research period were too short in time series, so changes are not reflected clearly across localities. Besides, changes in the economic sector and the income per capita are not much different among the localities. Therefore, evidence is not strong enough to show the existing effects of these factors. However, the regression results show that the population factor significantly affects retail banking efficiency. The branches with larger population size mean that they have the potential for effective exploitation of the larger market. This result is similar to the studies of Noulas et al. (2008), Deville (2009) and Schaffnit et al. (1997).

The time factor: The results show that the coefficients are positive with a statistical significance level of $1 \%$, implying that the retail banking performance has improved, compared to 2015. The branch's business activities become more efficient over time, implying that branches in the MDR have a good level of adaptation to competition in the banking sector. Therefore, to improve and enhance their retail effectiveness, branches should focus on studies of adaptive strategies. This result is similar to previous studies such as Kwan and Eisenbeis (1997), Bhattacharyya et al. (1997) and Casu and Molyneux (2003).

Geographical characteristic factors: This factor is different from the specific characteristics of different 
Table 5: Tobit regression results

\begin{tabular}{|c|c|c|c|c|}
\hline Variables & Coefficient & Standard error & Multicollinear test (VIF) & T-test \\
\hline Quymo & $-0.1121^{* *}$ & $(0.049)$ & 1.79 & 0.0214 \\
\hline Sodiemgd & $-1.4417^{\star \star *}$ & $(0.435)$ & 1.98 & 0.0009 \\
\hline Antoanvon & $1.5923^{* * *}$ & $(0.447)$ & 2.38 & 0.0004 \\
\hline Tylenoxau & $-476.0608^{* * *}$ & $(119.352)$ & 2.69 & 0.0001 \\
\hline Rchinhanvien & $-1.1547^{\star *}$ & $(0.562)$ & 2.07 & 0.0399 \\
\hline Rchikhauhao & -0.1551 & $(0.535)$ & 1.49 & 0.7719 \\
\hline rchi_thu_hd & $-0.6491^{* * *}$ & $(0.222)$ & 1.81 & 0.0035 \\
\hline Tuoicn & $1.5559^{* * *}$ & $(0.436)$ & 2.51 & 0.0004 \\
\hline Tangtruong & 0.5468 & $(0.768)$ & 1.78 & 0.4766 \\
\hline Thunhap & 0.0114 & $(0.009)$ & 3.36 & 0.2082 \\
\hline Rdanso & $330.7291^{* * *}$ & $(94.233)$ & 3.54 & 0.0004 \\
\hline \multicolumn{5}{|l|}{ Time Factor } \\
\hline 2016.year & $1.3823^{* * *}$ & $(0.450)$ & & \\
\hline 2017.year & $2.8694^{* * *}$ & $(0.897)$ & & \\
\hline 2018.year & $4.4185^{\star \star *}$ & $(1.336)$ & & \\
\hline \multicolumn{5}{|l|}{ Geographical Factor } \\
\hline 2.Bac Lieu.idprovince & $7.2731^{* * *}$ & (1.919) & & \\
\hline 3.Ben Tre.idprovince & $14.4187^{* * *}$ & $(3.957)$ & & \\
\hline 4.Ca Mau.idprovince & $13.1127^{* * *}$ & $(3.689)$ & & \\
\hline 5.Can Tho.idprovince & $13.5801^{* * *}$ & $(3.803)$ & & \\
\hline 6.Dong Thap.idprovince & $16.1425^{* * *}$ & $(4.404)$ & & \\
\hline 8.Kien Giang.idprovince & $23.2369^{* * *}$ & $(6.646)$ & & \\
\hline 9.Long An.idprovince & $16.9042^{* * *}$ & $(4.627)$ & & \\
\hline 10.Soc Trang.idprovince & $7.3323^{* * *}$ & $(2.028)$ & & \\
\hline 11.Tien Giang.idprovince & $19.1479^{* * *}$ & $(5.540)$ & & \\
\hline 12.Tra Vinh.idprovince & $6.9485^{* * *}$ & $(1.890)$ & & \\
\hline 13.Vinh Long.idprovince & $8.1067^{* * *}$ & $(2.304)$ & & \\
\hline Coefficient & $7.2554^{* * *}$ & $(1.778)$ & & \\
\hline /sigma_u & 0.0000 & $(0.012)$ & & \\
\hline /sigma_e & $0.0876^{* * *}$ & $(0.009)$ & & \\
\hline Number of observations & 60 & 60 & & \\
\hline Number of branches observations & 15 & 15 & & \\
\hline Years of observation & 4 & 4 & & \\
\hline Model & & & 2.31 & 0.0003 \\
\hline Wald test & $\begin{array}{l}\text { Wald chi2(25) } \\
\quad=635.88\end{array}$ & $\begin{array}{c}\text { Prob }>\text { chi2 }= \\
0.0000\end{array}$ & & \\
\hline
\end{tabular}

Note the significance level: ${ }^{* *} p<0.01,{ }^{* *} p<0.05,{ }^{*} p<0.10$ 
localities. The results are similar to those of previous studies such as Schaffnit et al. (1997), Stewart et al. (2016), Das et al. (2009), Deville (2009), Paradia et al. (2011) and Noulas et al. (2008). Comparing to the branches in An Giang, the branches in other localities have significant different technical efficiency scores at $\mathrm{P}<0.01$. This implies that geographical characteristic factors have great influences on retail banking efficiency. Indeed, studying about culture, living errors, customs and habits of each locality will help the branches to grasp better customer decision-making behaviors. Then, they have better preparation for marketing strategies, expanding markets, diversifying products, developing new retail products following local characteristics.

\section{Conclusion}

The objective of this paper is to evaluate retail banking efficiency of 15 VCB branches in the MDR from 2015 to 2018. The study estimated DEA score and combined with a Tobit regression model to evaluate factors affecting retail banking efficiency. The results show that scale, capital adequacy, credit quality, labor cost, experience, potential market size, environmental adaptation over time, and geographical adaptation have significant effects on retail banking efficiency. Besides, categorized by ranking (A, B, C) in 2018, the branches at An Giang, Can Tho, Dong Thap, Kien Giang, Long An, Phu Quoc and Tra Noc have high retail efficiency (group A). Category B (medium efficiency) includes branches in Soc Trang, Tien Giang and Vinh Long. Category $\mathrm{C}$ (poor efficiency) includes branches in Bac Lieu, Ben Tre, Ca Mau, Chau Doc and Tra Vinh.

This research is expected to be make important contributions to empirical research in the field of retail banking efficiency at the branch level. For enhancing managing performance, the paper also points out some aspects that need to be improved for retail banking activities in the future. However, this study has not fully reflected the real fluctuations of retail banking efficiency. Future studies could incorporate many other approaches to capture the real trend of the fluctuations in retail banking efficiency over time beside a DEA estimate.

\section{References}

Abdul-Majid, M., Saal, D. S., \& Battisti, G. (2010). Efficiency in Islamic and conventional banking: An international comparison. Journal of Productivity Analysis, 34(1), 25-43. https://doi.org/10.1007/s11123-009-0165-3

Adusei, M. (2016). Determinants of bank technical efficiency: Evidence from rural and community banks in Ghana. Cogent Business \& Management, 3(1), 0. https://doi.org/10.1080/233 11975.2016.1199519
Andries, A. M. (2011). The Determinants of Bank Efficiency and Productivity Growth in the Central and Eastern European Banking Systems. Eastern European Economics, 49(6), 38-59. https://doi.org/10.2753/EEE0012-8775490603

Avkiran, N. K. (1999). An application reference for data envelopment analysis in branch banking: helping the novice researcher. International Journal of Bank Marketing, 17(5), 206-220. https://doi.org/10.1108/02652329910292675

Banker, R. D., Charnes, A., \& Cooper, W. W. (1984). Some Models for Estimating Technical and Scale Inefficiencies in Data Envelopment Analysis. Management Science, 30(9), 10781092. https://doi.org/10.1287/mnsc.30.9.1078

Banna, H., Ahmad, R., \& Koh, E. H. Y. (2017). Determinants of Commercial Banks' Efficiency in Bangladesh: Does Crisis Matter? Journal of Asian Finance, Economics and Business, 4(3), 19-26. http://dx.doi.org/10.13106/jafeb.2017.vol4.no3.19

Barros, C. P., Ferreira, C., \& Williams, J. (2007). Analysing the determinants of performance of best and worst European banks: A mixed logit approach. Journal of Banking \& Finance, 31(7), 2189-2203. https://doi.org/10.1016/j.jbankfin.2006.11.010

Batir, T. E., Volkman, D. A., \& Gungor, B. (2017). Determinants of bank efficiency in Turkey: Participation banks versus conventional banks. Borsa Istanbul Review, 17(2), 86-96. https://doi.org/10.1016/j.bir.2017.02.003

Bauer, P. W., Berger, A. N., Ferrier, G. D., \& Humphrey, D. B. (1998). Consistency Conditions for Regulatory Analysis of Financial Institutions: A Comparison of Frontier Efficiency Methods. Journal of Economics and Business, 50(2), 85-114. https://doi.org/10.1016/S0148-6195(97)00072-6

Berger, A. N. (1993). "Distribution-Free" Estimates of Efficiency in the U.S. Banking Industry and Tests of the Standard Distributional Assumptions. Journal of Productivity Analysis, 4(3), 261-292. https://doi.org/10.1007/BF01073413

Berger, A. N., \& Mester, L. J. (1997). Inside the black box: What explains differences in the efficiencies of financial institutions? Journal of Banking \& Finance, 21(7), 895-947. https://doi. org/10.1016/s0378-4266(97)00010-1

Bhattacharyya, A., Lovell, C. A. K., \& Sahay, P. (1997). The impact of liberalization on the productive efficiency of Indian commercial banks. European Journal of Operational Research, 98(2), 332345. https://doi.org/10.1016/S0377-2217(96)00351-7

Boufounou, P. V. (1995). Evaluating bank branch location and performance: A case study. European Journal of Operational Research, 87(2), 389-402. https://doi.org/10.1016/03772217(92)00080-5

Camanho, A. S., \& Dyson, R. G. (2005a). Cost efficiency measurement with price uncertainty: a DEA application to bank branch assessments. European Journal of Operational Research, 161(2), 432-446. https://doi.org/10.1016/j. ejor.2003.07.018

Camanho, A. S., \& Dyson, R. G. (2005b). Cost efficiency, production and value-added models in the analysis of bank branch performance. Journal of the Operational Research 
Society, 56(5), 483-494. https://doi.org/10.1057/palgrave. jors. 2601839

Casu, B., \& Molyneux, P. (2003). A comparative study of efficiency in European banking. Applied Economics, 35(17), 1865-1876. https://doi.org/10.1080/0003684032000158109

Coelli, T. J., Rao, D. S. P., O’Donnell, C. J., \& Battese, G. E. (2005). An Introduction to Efficiency and Productivity Analysis (2 ed.). Boston, MA: Springer.

Cook, W. D., Hababou, M., \& Tuenter, H. J. H. (2000). Multicomponent Efficiency Measurement and Shared Inputs in Data Envelopment Analysis: An Application to Sales and Service Performance in Bank Branches. Journal of Productivity Analysis, 14(3), 209-224. https://doi. org/10.1023/A:1026598803764

Dao, B. T. T., \& Nguyen, D. P. (2020). Determinants of Profitability in Commercial Banks in Vietnam, Malaysia and Thailand. Journal of Asian Finance, Economics and Business, 7(4), 133143. https://doi.org/10.13106/jafeb.2020.vol7.no4.133

Das, A., Ray, S. C., \& Nag, A. (2009). Labor-use efficiency in Indian banking: A branch-level analysis. Omega, 37(2), 411425. https://doi.org/10.1016/j.omega.2007.05.002

Deville, A. (2009). Branch banking network assessment using DEA: A benchmarking analysis-A note. Management Accounting Research, 20(4), 252-261. https://doi.org/10.1016/j. mar.2009.08.001

Girardone, C., Molyneux, P., \& Gardener, E. P. M. (2004). Analysing the determinants of bank efficiency: the case of Italian banks. Applied Economic, 36(3), 215-227. https://doi. org/10.1080/0003684042000175334

GSO. (2018). Statistical Yearbook 2018. Ha Noi: General Statistics Office.

Hauner, D. (2005). Explaining efficiency differences among large German and Austrian banks. Applied Economics, 37(9), 969980. https://doi.org/10.1080/00036840500081820

Hensel, N. D. (2003). Strategic Management of Cost Efficiencies in Networks: Cross-country Evidence on European Branch Banking. European Financial Management, 9(3), 333-360. https://doi.org/10.1111/1468-036X.00224

Kaparakis, E. I., Miller, S. M., \& Noulas, A. G. (1994). Short-run cost inefficiency of commercial banks : a flexible stochastic frontier approach. Journal of Money, Credit and Banking, 26(4), 875-893. https://doi.org/10.2307/2077953

Kwan, S. H., \& Eisenbeis, R. (1997). Bank Risk, Capitalization, and Operating Efficiency. Journal of Financial Services Research, 12(2/3), 117-131. https://doi.org/10.1023/A:1007970618648

LaPlante, A. E., \& Paradi, J. (2015). Evaluation of bank branch growth potential using data envelopment analysis. Omega, 52, 33-41. https://doi.org/10.1016/j.omega.2014.10.009

Majeed, M. K., Jun, J. C., Zia-Ur-Rehman, M., Mohsin, M., \& Rafiq, M. Z. (2020). The Board Size and Board Composition Impact on Financial Performance: An Evidence from the Pakistani and Chinese's Listed Banking Sector. Journal of
Asian Finance, Economics and Business, 7(4), 81-95. https:// doi.org/10.13106/jafeb.2020.vol7.no4.81

Manlagñit, M. C. V. (2011). Cost efficiency, determinants, and risk preferences in banking: A case of stochastic frontier analysis in the Philippines. Journal of Asian Economics, 22(1), 23-35. https://doi.org/10.1016/j.asieco.2010.10.001

Mester, L. J. (1996). A study of bank efficiency taking into account risk-preferences. Journal of Banking \& Finance, 20(6), 10251045. https://doi.org/10.1016/0378-4266(95)00047-X

Molyneux, P., \& Thornton, J. (1992). Determinants of European bank profitability: A note. Journal of Banking \& Finance, 16(6), 1173-1178. https://doi.org/10.1016/0378-4266(92)90065-8

Murphy, N. B., \& Orgler, Y. E. (1982). Cost analysis for branching systems: Methodology, test results, and implications for management. Journal of Financial Research, 5(2), 181-188. https://doi.org/10.1111/j.1475-6803.1982.tb00059.x

Ngan, T. H., Thao, T. P., \& Huan, N. H. (2015). Impact of Restructuring on Efficiency of Vietnam's Commercial Banks. Journal of Economic Development, 22(2), 27-47. https://doi. org/10.24311/jed/2015.22.2.05

Ngo, D. T. (2010). Evaluating the Efficiency of Vietnamese Banking System: An Application Using Data Envelopment Analysis. SSRN Electronic Journal. https://doi.org/10.2139/ssrn.1626009

Ngo, D. T. (2015). Efficiency of the banking system in Vietnam under financial liberalization. Manawatu, New Zealand: Doctoral dissertation, Massey University. Retrieved from http://hdl.handle.net/10179/7208

Nguyen, P. A., \& Simioni, M. (2015). Productivity and efficiency of Vietnamese banking system: new evidence using Färe-Primont index analysis. Applied Economics, 47(41), 4395-4407. https:// doi.org/10.1080/00036846.2015.1030565

Noulas, A. G., Glaveli, N., \& Kiriakopoulos, L. (2008). Investigating cost efficiency in the branch network of a Greek bank: an empirical study. Managerial Finance, 34(3), 160-171. https://doi.org/10.1108/03074350810848045

Othman, N., Abdul-Majid, M., \& Rahman, A. A. (2017). Partnership financing and bank efficiency. Pacific-Basin Finance Journal, 46, 1-13. https://doi.org/10.1016/j.pacfin.2017.08.002

Paradi, J. C., \& Zhu, H. (2013). A survey on bank branch efficiency and performance research with data envelopment analysis. Omega, 41(1), 61-79. https://doi.org/10.1016/j. omega.2011.08.010

Paradia, J. C., Rouatt, S., \& Zhu, H. (2011). Two-stage evaluation of bank branch efficiency using data envelopment analysis. Omega, 39(1), 99-109. https://doi.org/10.1016/j.omega.2010.04.002

Quaranta,A. G., Raffoni, A., \& Visani, F. (2018). A multidimensional approach to measuring bank branch efficiency. European Journal of Operational Research, 266(2), 746-760. https://doi. org/10.1016/j.ejor.2017.10.009

Sarmiento, M., \& Galán, J. E. (2017). The influence of risk-taking on bank efficiency: Evidence from Colombia. Emerging Markets Review, 32, 52-73. https://doi.org/10.1016/j. ememar.2017.05.007 
Schaffnit, C., Rosen, D., \& Paradi, J. C. (1997). Best practice analysis of bank branches: An application of DEA in a large Canadian bank. European Journal of Operational Research, 98(2), 269289. https://doi.org/10.1016/S0377-2217(96)00347-5

Sharma, D., Sharma, A. K., \& Barua, M. K. (2013). Efficiency and productivity of banking sector: A critical analysis of literature and design of conceptual model. Qualitative Research in Financial Markets, 5(2), 195-224. https://doi.org/10.1108/ QRFM-10-2011-0025

Sherman, H. D., \& Gold, F. (1985). Bank branch operating efficiency: Evaluation with Data Envelopment Analysis. Journal of Banking \& Finance, 9(2), 297-315. https://doi. org/10.1016/0378-4266(85)90025-1

Soteriou, A. C., Karahanna, E., Papanastasiou, C., \& Diakourakis, M. S. (1998). Using DEA to evaluate the efficiency of secondary schools: the case of Cyprus. International Journal of Educational Management, 12(2), 65-73. https://doi. org/10.1108/09513549810204441

Stewart, C., Matousek, R., \& Nguyen, T. N. (2016). Efficiency in the Vietnamese banking system: A DEA double bootstrap approach. Research in International Business and Finance, 36, 96-111. https://doi.org/10.1016/j.ribaf.2015.09.006

Vallascas, F., \& Keasey, K. (2012). Bank resilience to systemic shocks and the stability of banking systems: Small is beautiful. Journal of International Money and Finance, 31(6), 17451776. https://doi.org/10.1016/j.jimonfin.2012.03.011

Vietcombank. (2018). 2018 Annual Report: Breaking with the digital banking revolution. Retrieved from Ha Noi: https:// portal.vietcombank.com.vn/Investors/Pages/chi-tiet-nha-dautu.aspx?ItemID=1087\&devicechannel=default 